\title{
THE INFLUENCE OF PURCHASING ORGANIC FOOD AMONG EXPATRIATES IN INDONESIA
}

\author{
Genoveva Genoveva*), Akram Alamodi*) \\ ${ }^{*}$ School of Business, President University \\ Jl. Ki Hajar Dewantara, Kota Jababeka, Cikarang Baru, Bekasi 17550, Indonesia
}

\begin{abstract}
The purpose of this study was to explore the factors that influence purchasing decisions expart to organic food. Environmental issues make a number ofmany people pay special attention to environmental sustainability. In Indonesia, a healthy lifestyle by consuming organic products has become a trend among the upper- middle class of some Indonesians, but most of the consumers of organic food in Indonesia are expatriates. The variables that influence the decision to purchase organic food that will be used in this research are Customer Attitude, Personal Norms, Social Norms, Impending Barriers and Marketing Strategies on Purchase Decisions. This study is a quantitative research using online questionnaires in data collection. Respondents are expatriates in greater Jakarta, as many as 165 people. The data is processed by SPSS. The findings of this study are consumer attitudes, personal norms, and marketing strategies have a significant influence on purchasing decisions, while social norms and future barriers do not. The variable that most influences the decision to purchase organic food is the marketing strategies which contributes $33.6 \%$.
\end{abstract}

Keywords: customer attitude, impending barriers, marketing strategies, personal norm, social norms

\begin{abstract}
Abstrak: Tujuan penelitian ini adalah menggali faktor-faktor yang memengaruhi keputusan pembelian expart terhadap makanan organic. Isu lingkungan membuat sejumlah orang menaruh perhatian khusus pada kelestarian lingkungan. Di Indonesia, pola hidup sehat dengan mengonsumsi produk organik telah menjadi trend di kalangan menengah ke atas sebagian masyarakat Indonesia, namun sebagian konsumen makanan organik di Indonesia adalah para ekspatriat. Adapun variable yang mempengaruhi keputusan pembelian makanan organik yang akan digunakan dalan penelitian ini adalah Perilaku Konsumen, Normal Pribadi, Norma Sosial, Hambatan dan Strategi Pemasaran terhadap Keputusan Pembelian. Studi ini merupakan peneitian kuantitatif dengan menggunakan kuesioner online dalam pengumpulan data. Responden adalah para expatriat di greater Jakarta, sebanyak 165 orang. Data diolah dengan SPSS. Temuan penelitian ini adalah sikap konsumen, norma pribadi, dan implikasi pemasaran memiliki pengaruh yang signifikan terhadap keputusan pembelian, sedangkan norma sosial dan hambatan masa depan tidak memilikinya. Variabel yang paling mempengaruhi keputusan pembelian makanan organik adalah strategi pemasaran yang memberikan kontribusi sebesar 33,6\%.
\end{abstract}

Kata kunci: hambatan, norma pribadi, norma sosial, perilaku konsumen, strategi pemasaran

\footnotetext{
${ }^{1}$ Corresponding author:

Email: genoveva@president.ac.id
} 


\section{INTRODUCTION}

Sustainability is an issue in the business world that is getting more attention from year to year (Curvelo et al. 2019). The movement of people who care about these is a group of called green consumers (Peattie, 2010). The existence of green consumer grows and forces the industry to care more about the environment and be able to create environmentally friendly products demand in the food sector, namely organic products, has increased quite significantly (Hawkins and Mothersbaugh, 2015; Sharma and Triveldi, 2016; Genoveva and Berliana, 2021). This community group is consumers who continuously incorporate this product into their daily eating habits (Aschemann-Witzel, 2010). This is explained by changes in their attitudes, beliefs, values and motivations, and by a more critical position regarding food safety and consumption of processed foods (Wilcock et al. 2004; Nocella, 2012).

Attitude is a consideration in certain behaviors, such ascarrying out certain behaviors, for example attitudes towards products purchased. Attitudes related to morals in consumption indicate consumer decisions in buying (Setiawati et al. 2019). As it relates to organic foods, consumer attitude and the behavior to purchase organic foods areis strongly influenced by the benefits the food provides to human health (Ueasangkomsatea and Santiteerakulb, 2016). Besides attitude, social norms also affect a person in making purchasing decisions, the influence of friends, family and social pressures faced by a person related to individual references in making buying decisions (Aertsens et al. 2009; Han and Stoel, 2016). However, personal or moral norms refer to an individual's beliefs about how he or she acts in a certain (Aertsens et al. 2009). Personal norms can also be referred as how an individual conceptualizes moral as attributed to a specific conduct with compliance resulting in feeling proud while non-compliance results in shame or guilt (Onwezen, 2015). Personal norms also strengthen a person in making purchasing decisions (Setiawati et al. 2019).

A healthy lifestyle by consuming organic products has become a trend among the upper middle class of some Indonesians. The trend of healthy lifestyles among people by consuming organic products is still facing obstacles, the number of requests tends to be stagnant because of cost barrier (Suharjo et al. 2016). Organizations like Yayasan Usaha Mulia, better known as YUM, has taken this idea to heart and since 2010 has focused on connecting organic farmers with buyers. Vanessa Reksodipoetro, communication and partner relations coordinator at YUM, heads a project that provides a bi-weekly organic products delivery from their farm project in Cipanas to urban Jakarta who otherwise have a hard time connecting with farmers. But despite their efforts Vanessa claims that out of their 300 or so clients, only around 25 percent of their customers are Indonesians, and the rest are expatriates. These numbers can't keep a business growing for long, where you can't rely on around 300 clients for a whole business. She said usually, people buy from their local pasar (market), and tukang sayur (vendors), for them it's habit and it's easy, moreover the price and availability of products. Because organic product costlier and it's not easy to find around you, where clients must go to certain market, that leads clients to buy from markets around them (Widjajakusumah, 2018).

For accuracy in predicting consumer behavior, marketing strategies related to distribution channels play an important role in attracting core organic consumers (Nugroho et al. 2015). The specialty organic shop has a variety of certified organic foods and compared to conventional stores, attracts more organic food consumers (Li and Xin, 2015). Purchasing decision is a process that buyer takes outis taken out by buyer to achieve their needs and gain high satisfaction (Utami and Genoveva, 2020). One of the key aspects that influence purchase decisions by consumers, when it comes to organic foods, is the perception they have concerned with organic products. Based on the problems, the researchers assume that customer's attitude, social norms, personal norms, impending barriers and marketing strategies influence consumer purchasing decisions of organic food.

\section{METHODS}

This study uses five independent variables, namely Customer Attitude, Social Norms, Subjective Norm, Impending barriers, and Marketing Strategies. While the dependent variable used is Purchase Decision. The data collection tool used is an online questionnaire distributed to respondents on July 2021, using judgement sampling technique, namely through the expat online community in Indonesia. The total number of respondents is 165 based on (Hair et al. 2014) this number has met the requirements, where the minimum indicator is multiplied by 5 . The indicators in the 
questionnaire are five for each variable, bringing the total to 30 indicators. Where the respondents needed to answer to the statements using the Likert scale (1-5). The questionnaire is designed in three parts, namely screening questions to find out whether they are organic food consumers, if they meet the requirements as organic food consumers, the questions can be continued. The second part is the profile of the respondents and the last part is the questions related to the research variables variables. Finally, the data is processed using SPSS. SPSS was chosen because the number of respondents was not large, namely 165 and the test used multiple regression in this study.

This study consists of six hypotheses (Figure 1), namely five partial hypotheses and one simultaneous hypothesis. Because mostly the organic food customers in Indonesia are expatriates, this study uses expatriate samples as respondents. Expart is a foreigner who resides in a country (Selmer, 2019), in this study is a foreign citizen domiciled in Indonesia, especially greater Jakarta. To our best knowledge, this is the first study related to organic food purchasing decisions using expatriates as respondents. This research also inline with several authors (Ham et al. 2015; Li and Xin, 2015; Bai et al. 2019).

\section{RESULTS}

\section{Respondent Profile}

The profile of respondents (Table 1) based on gender consisted of 74 males (45\%) and 91 females (55\%). Meanwhile, based on age, the most were in the age group of 28-38 years as many as 61 respondents (37\%), followed by the age group 39-49 years with 52 respondents (32\%), then $17-27$ years old with 32 respondents (19\%), the rest are the age group above 49 years amounting to 20 respondents $(12 \%)$. The majority of respondents' jobs are employees with 46 respondents $(27 \%)$, then others consisting of housewives, retirees, freelancers, artists, 40 respondents (25\%), professionals with 36 respondents (22\%), entrepreneur 28 respondents $(17 \%)$, and the rest students 15 respondents (9\%).

\section{Validity Analysis}

Pearson's Correlation Coefficient can be used to predict questionnaires validity. Validity of the question is evident if the critical values for Pearson correlation table (R-table) are lower than Pearson's Correlation Coefficient (R). From the R-table, given our $\mathrm{df}$ is 28 (30-2) at 0.05 , we get a critical value of 0.361 as we can see in Table 2 that all $R$ value for every single question was greater than 0.361 , hence we can conclude that all questions are valid.

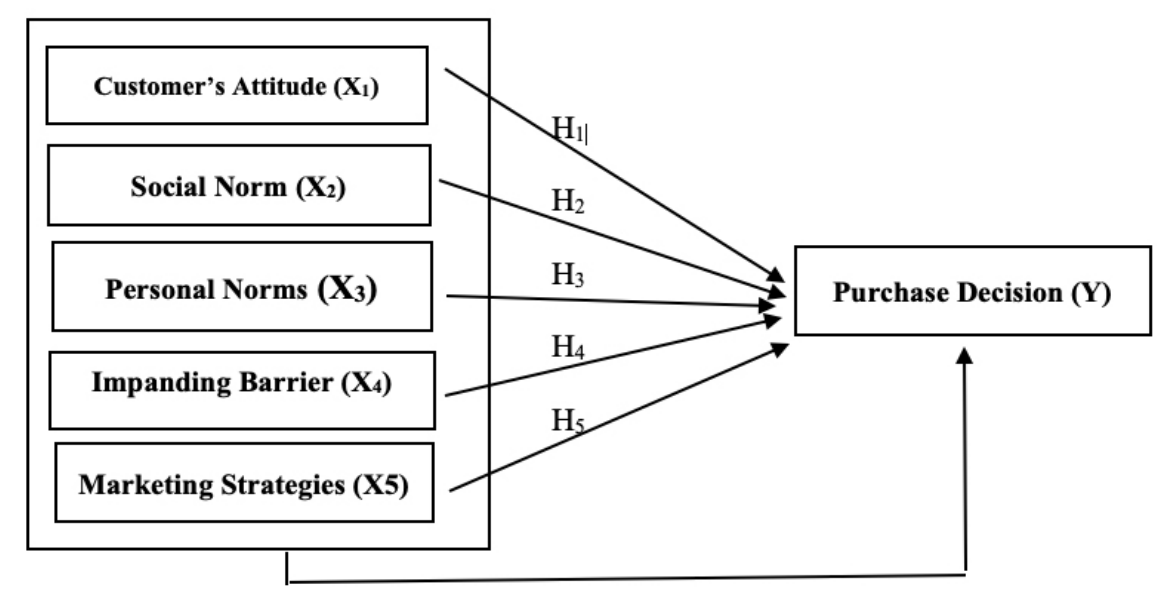

Figure 1. Research framework 
Table 1. Respondent profile

\begin{tabular}{|c|c|c|c|}
\hline Characteristics & & Total & Percentage \\
\hline \multirow[t]{2}{*}{ Gender } & Male & 74 & $45 \%$ \\
\hline & Female & 91 & $55 \%$ \\
\hline \multirow[t]{4}{*}{ Age } & $17-27$ years old & 32 & $19 \%$ \\
\hline & 28-38 years old & 61 & $37 \%$ \\
\hline & 39-49 years old & 52 & $32 \%$ \\
\hline & $>49$ years old & 20 & $12 \%$ \\
\hline \multirow[t]{5}{*}{ Occupation } & Student & 15 & $9 \%$ \\
\hline & Entrepreneur & 28 & $17 \%$ \\
\hline & Professional & 36 & $22 \%$ \\
\hline & Employee & 46 & $27 \%$ \\
\hline & Others & 40 & $25 \%$ \\
\hline
\end{tabular}

Table 2. Validity result

\begin{tabular}{|c|c|c|c|c|}
\hline Variable & Question & R-table & $\mathrm{R}$ & Decision \\
\hline \multirow{5}{*}{$\begin{array}{l}\text { Customer's Attitude } \\
\text { (X1) }\end{array}$} & CAI & 0.361 & .741 & valid \\
\hline & CA2 & 0.361 & .742 & valid \\
\hline & CA3 & 0.361 & .767 & valid \\
\hline & CA4 & 0.361 & .808 & valid \\
\hline & CA5 & 0.361 & .697 & valid \\
\hline \multirow[t]{5}{*}{ Personal Norms (X2) } & PA1 & 0.361 & .669 & valid \\
\hline & PA2 & 0.361 & .695 & valid \\
\hline & PA3 & 0.361 & .663 & valid \\
\hline & PA4 & 0.361 & .765 & valid \\
\hline & PA5 & 0.361 & .682 & valid \\
\hline \multirow[t]{5}{*}{ Social Norms (X3) } & SN1 & 0.361 & .451 & valid \\
\hline & $\mathrm{SN} 2$ & 0.361 & .621 & valid \\
\hline & SN3 & 0.361 & .754 & valid \\
\hline & SN4 & 0.361 & .736 & Valid \\
\hline & SN5 & 0.361 & .779 & Valid \\
\hline \multirow{5}{*}{$\begin{array}{l}\text { Impending Barriers } \\
\text { (X4) }\end{array}$} & IB1 & 0.361 & .725 & Valid \\
\hline & IB 2 & 0.361 & .683 & Valid \\
\hline & IB3 & 0.361 & .642 & Valid \\
\hline & IB4 & 0.361 & .433 & Valid \\
\hline & IB5 & 0.361 & .711 & Valid \\
\hline \multirow{5}{*}{$\begin{array}{l}\text { Marketing Strategies } \\
\text { (X5) }\end{array}$} & MI1 & 0.361 & .601 & Valid \\
\hline & MI2 & 0.361 & .767 & Valid \\
\hline & MI3 & 0.361 & .746 & Valid \\
\hline & MI4 & 0.361 & .897 & Valid \\
\hline & MI5 & 0.361 & .592 & Valid \\
\hline \multirow[t]{5}{*}{ Purchase Decision $(\mathrm{Y})$} & Y1 & 0.361 & .866 & Valid \\
\hline & $\mathrm{Y} 2$ & 0.361 & .723 & Valid \\
\hline & Y3 & 0.361 & .854 & Valid \\
\hline & Y4 & 0.361 & .806 & Valid \\
\hline & Y5 & 0.361 & .798 & Valid \\
\hline
\end{tabular}




\section{Reliability Analysis}

According to (Ursachi et al. 2015), variables are deemed reliable if their respective Cronbach's alpha coefficient is bigger than 0.6. Results from the Table 3 , all variables were significantly reliable. We can conclude that all variables are reliable because the Cronbach alpha is greater than 0.6.

\section{Descriptive Statistics}

Below results is used to determine the most dominant dependent variable associated with the decition to purchase organic foods. From the Table 4, it can be seen that the Attitude held by consumers with respect to organic foods is the most dominant independent variable when determining to purchase organic foods. Followed in a subsequent order by the results reveal that Social Norms, Personal Norms, Marketing Strategies and Impending Barrier had influence in how consumers perceive organic foods.

\section{Normality Test}

Assessment of data normality is a pre-requisite to see if the data is normally distributed so that it meets the requirements for the next test (Mishra et al. 2019). From the results of the P-P Plot test, all data points are aligned along the most appropriate line (diagonal line). This means the data is normally distributed. The image in the histogram also shows an inverted bell, a good predictor of a normal distribution. The scatterplot image shows scattered points and does not form a certain pattern, there is no case of heteroscedaticity. Multicollinearity data also supports, where the tolerance value is above $1.0(1.0<)$ and the variance inflation Factor (VIF) below 10 (VIF $>10)$, then, the independent variables lack Multicollinearity.

\section{Multiple Regression}

For every independent variable, T-test can be used to show the significant impact of each variable on dependent variable at 0.05 . Notably, the impact is significant is the $\mathrm{P}$ value is less than 0.05 . The data (Table 5) show Social Norms and Impending Barriers are $>0.05$. This means that only Customer's Attitude, Personal Norms and marketing Strategies have a significant and positive impact on respondents purchase decision. Consequently, the model can be updated further to equation.

$$
\begin{aligned}
Y= & 4.239(\text { Constant })+0.289\left(X_{1}\right)+0.208\left(X_{3}\right)+ \\
& 0.336\left(X_{5}\right)
\end{aligned}
$$

Where: Y (Purchase Decision); $\mathrm{X}_{1}$ (Customer's Attitude); $\mathrm{X}_{2}$ (Social norms); $\mathrm{X}_{3}$ (Personal Norms); $\mathrm{X}_{4}$ (Impending barriers); $\mathrm{X}_{5}$ (marketing Strategies).

Marketing Strategies $\left(\mathrm{X}_{5}\right)$ gave the largest contribution to the Purchasing Decision, which was 33.6\%, Customer Attitude $\left(\mathrm{X}_{1}\right)$ was in second place with a contribution of $28.9 \%$ and the last was Personal Norms $\left(\mathrm{X}_{3}\right)$ at $20.8 \%$.

Table 3. Reliability result

\begin{tabular}{lcc}
\hline Variable & Cronbach's alpha & Number of items \\
\hline Customer's Attitude (X1) & 0.809 & 5 \\
Social Norms (X2) & 0.743 & 5 \\
Personal Norms (X3) & 0.704 & 5 \\
Impending Barriers (X4) & 0.639 & 5 \\
Marketing Strategies (X5) & 0.773 & 5 \\
Purchase Decision (Y) & 0.870 & 5 \\
\hline
\end{tabular}

Table 4. Descriptive result

\begin{tabular}{lccc}
\hline Variable & $\mathrm{N}$ & Mean & Std. Deviation \\
\hline Customer's Attitude (X1) & 165 & 4.42 & 0.70 \\
Social Norms (X2) & 165 & 4.02 & 0.82 \\
Personal Norms (X3) & 165 & 3.98 & 0.82 \\
Impending Barriers (X4) & 165 & 3.14 & 1.04 \\
Marketing Strategies (X5) & 165 & 3.81 & 1.03 \\
Purchase Decision (Y) & 165 & 4.29 & 0.83 \\
\hline
\end{tabular}




\section{F-test}

We used 165 respondents and 5 independent variables at 0.05 significant level. Consequently, since the $\mathrm{df}_{\mathrm{b}}$ is 4 (5-1) and $\mathrm{df}_{\mathrm{w}}$ is 160 (165-5), the $\mathrm{F}$ critical value will be 2.43. Based on Table 6, the F statistic (20.376) is bigger that $F$ critical value 2.43 . Similarly, the $P$ value $(0.000)$ is less than 0.05. Hence, we reject the null and assume the alternative hypothesis that there is a combined effect of Customer's Attitude, Social norms, Personal Norms, Impending Barriers and Marketing Strategies on Purchase decision of organic foods.

Our first hypothesis $\left(\mathrm{H}_{1}\right)$ was accepted, customers attitude significantly affect intention to purchase organic food. Attitude is a settled way of thinking about something. Customer attitude is how a customer feels about a product. The feeling is usually subjective and plays a significant role in determining whether a customer purchase something or not. In this case, it is the customer's attitude toward purchasing organic food. Understanding customers' perspectives regarding their intention to purchase organic food will help the stakeholders develop marketing strategies to develop such products (Wang et al. 2019). To appreciate the importance of the customers' perspective, the stakeholders need to know what influences their decision making. Most of the time, customers use available knowledge to draw their conclusions. Therefore, with proper advertisement and marketing, the customers thought process could be influenced for or against organic food products. Food safety is the customer's primary concern (Wang et al. 2019). Other factors that influence customer attitude towards buying organic food as established by a review of the existing literature are the health content, local origin, and environmental awareness, including animal welfare (Lee et al. 2019). People tend to purchase organic foods for safety reasons. With organic foods, the perception is that they are generally safer than conventional health products (Wang et al. 2019). According (Lee et al. 2019), health content is a trust issue for a consumer. According to the same article, relevant research has confirmed that customers trust organic foods' health content, which results in increased buying. This perception is influenced by the fact that organic foods' health content includes safety, quality, nutritional ingredients, and taste that create positive attitudes in consumers towards such foods. With the perception that organic foods are produced by means that harmless to the environment, environmentally conscious consumers will buy (Laureti and Benedetti, 2018). This is also true when dealing with animals. The food source is very vital in determining whether the customer will make a purchase or not (Lee et al. 2019). This is so because customers can only buy their products from places they trust.

Table 5. Multiple regression result

\begin{tabular}{|c|c|c|c|c|c|c|}
\hline \multicolumn{7}{|c|}{ Coefficients $^{\mathrm{a}}$} \\
\hline & \multirow{2}{*}{ Model } & \multicolumn{2}{|c|}{ Unstandardized Coefficients } & \multirow{2}{*}{$\begin{array}{c}\text { Standardized Coefficients } \\
\text { Beta } \\
\end{array}$} & \multirow{2}{*}{$\mathrm{t}$} & \multirow{2}{*}{ Sig. } \\
\hline & & $\mathrm{B}$ & Std. Error & & & \\
\hline \multirow[t]{6}{*}{1} & (Constant) & 4.239 & 2.042 & & 2.076 & .040 \\
\hline & TOTX1 & .289 & .084 & .244 & 3.436 & .001 \\
\hline & TOTX2 & -.022 & .080 & -.020 & -.276 & .783 \\
\hline & TOTX3 & .208 & .096 & .165 & 2.161 & .032 \\
\hline & TOTX4 & .046 & .067 & .050 & .691 & .491 \\
\hline & TOTX5 & .336 & .064 & .396 & 5.244 & .000 \\
\hline
\end{tabular}

a. Dependent Variable: TOTY

Table 6. F-Test Result (Annova)

\begin{tabular}{llccccc}
\hline Model & & Sum of Squares & df & Mean Square & F & Sig. \\
\hline 1 & Regression & 617.052 & 4 & 123.410 & 20.376 & $.000 \mathrm{a}$ \\
& Residual & 932.723 & 160 & 6.057 & & \\
& Total & 1549.775 & 165 & & & \\
\hline
\end{tabular}


Our second hypothesis $\left(\mathrm{H}_{2}\right)$ was declined, Social Norms does not significantly affect intention to purchase organic food. This contradicts numerous studies who believe that social norms are the unwritten rules about how to behave. They generally apply to a society or a group. They provide an idea of how to behave in a particular social group or culture. Values can affect how society perceives a particular organic product. These will eventually affect an individual's thinking within that society (Vega-Zamora et al. 2020). Social norms are based on motivation to comply with and normative beliefs with the wishes of other people. Arque by (Teng and Wang, 2015), when people are significant to others, they tend to have positive opinions and attitudes concerning organic food and are more likely to experience a positive intention for purchasing organic food products (Teng and Wang, 2015). From the literature reviewed, it is evident that what has been normalized in a group of people is vital in determining whether an individual will purchase organic food or not. With the growing amount of information on food products, the individual's values are always changing. The information has increased the role of values in consumption, given that we can no longer plead ignorance to justify certain behaviours (Vega-Zamora et al. 2020). There are two distinct types of social norms, injunctive and descriptive norms. While injunctive norms refer to rules or beliefs that ought to be done and seem morally approved or disapproved, descriptive norms refer to what is done (Gruchmann and Wenzig, 2018). This usually affects how people approach the buying of organic foods.

Our third hypothesis $\left(\mathrm{H}_{3}\right)$ was proved, personal Norms significantly affect intention to purchase organic food. Personal norms have been defined as a selfexpectation of specific action in a particular situation that is usually experienced as a moral expectation (Jansson and Dorrepaal, 2015). Therefore, personal norms are adhered to because of internal reasons that are consistent with internal values. The article further affirms a positive correlation between personal norms and pro-environmental behavior such as recycling, switching to environmentally friendly alternatives, consumer purchase of environmentally friendly products, and organic food or wine (Jansson and Dorrepaal, 2015). It is hypothesized that personal norms have a positive impact on an individual's behavior towards environmental protection. An individual's expectation of themselves greatly influences their environmental consciousness. The individual's social construct also affects their behavior towards the environment. Therefore, social norms are also an essential consideration for purchasing organic food and the consumer's need to care for the environment (Bai and Bai, 2020). Consumption values and self-identity are essential for sustainable consumer behavior. Environmental self-identity significantly mediates the structural relationship between consumption values and the behavioural intention to consume organic food (Qasim et al. 2019).

Our fourth hypothesis $\left(\mathrm{H}_{4}\right)$ was declined, the relationship between impending barriers on intention to purchase organic food is that impending barriers does not affect intention to purchase organic food. Factors such as cost, accessibility and lack of information significantly affect the intention of the consumer to purchase organic food (Chiciudean et al. 2019). In this study however, impending barriers has no significance effect to consumer intentions of purchasing organic food. These results conflicts with previous literature carried out by (Ruiz et al. 2018). Who argued that factors such as hike in cost makes consumers with relatively low income to shift to other alternative products that have the same nutritional content value. It therefore means that consumers do not attach factors such as cost, information and accessibility. Consumers put more emphasis on the nutritional content and their medicinal value (Dhanavath and Rao, 2017). Consumers are willing to spend extra money and look for more information about organic food through sources such as the internet and magazines that focus on health and wellness (Choi, 2011). Choi (2011) assert that there exists different sources information for organic food which are available to consumers, current health concerns have forced stakeholders and policy makers to make information available to consumers.

Our fifth hypotesis $\left(\mathrm{H}_{5}\right)$ was accepted, the relationship between marketing Strategies effects and consumer's intention to purchase organic food is that marketing Strategies has significant effects on consumers'intention to purchase organic food. From data analysis, marketing implication had a significance of 0.000 which is lower than beta coefficient. The results concur with the past literature. A study by (Ghosh et al. 2018) found out that consumer involvement through promotional strategies such as demonstration influences their buying decisions. Firms that carry out intensive promotion of organic food products recorded significant sales compared to those that use ineffective marketing strategies. Marketing 
strategies such as advertisement, sales promotion and packaging strategies had strong influence on consumers purchasing decisions. Marketing Strategies have the effect of persuading consumers to purchase a product, how the company uses these strategies plays a key role in pushing sales volume. There is a strong positive correlation between marketing, sociopsychological factors and organic food purchase (Duh, 2019). Psychological pricing factors influence consumers buying decisions, consumers with relatively low disposable income prefer to purchase cheap food items. They resort to alternative food products which are cheaper but have the same content as nutritional content as organic food item. Packaging also influences buyers' decision, products that have more appealing appearance attract more customers compared to those which look dull in appearance. A study by (Ririn et al. 2019) found that package, texture, color and material influence consumer purchasing behaviour. When product material composition is maintained and packaging material is altered, there will be an effect in sales, sales volume can either increase or decrease depending how consumer perceive product appearance in the market. Ririn et al. (2019) debunks the notion that value content and company reputation in the industry is what leads to increased sales volume, but rather, opines that successful companies push sales by developing a strong brand that proposes its value to the consumers through strong brand packaging.

Simultaneously $\left(\mathrm{H}_{6}\right)$, Attitude, Personal Norms, Social Norms, Impending Barriers and Marketing Strategies has significan effects on Purchase Decisions in buying organic foods. We combined several previous studies to obtain 5 independent variables and 1 dependent variable. Research by (Sundqvist, 2005) concludes that attitudes, personal norms and impending barriers in terms of price influence on purchasing decisions for organic food in the context of buying bread and flour organics. The same line was expressed by (Bai et al. 2019) that Attitude, personal norms (subjective norms) and impending barriers (income) affect the purchase of organic food in China. These two articles say that the barrier factor in purchasing decisions is price, because organic foods tend to be more expensive, and should be marketed according to the high economic level of consumers. For the younger group of respondents, apart from attitude, social norms influence green food purchasing decisions in Southern Europe (Ham et al. 2015). Finally, (Li and Xin, 2015) concluded that attitude, social norms, barriers and marketing Strategies affect the younger generation in China in making decisions to buy organic food.

\section{Managerial Implication}

The managerial implication this research to society are organic food can influence consumer's decision to purchase it in several ways, where they can conduct more awareness of organic to the sight of the consumers from its benefits for the person as well as for our environment, also the safety of it in where it's not added any extra chemical ingredients where it's purely fresh without adding any extra colour, taste, etc. moreover they could considers its price, the availability for all society in order for everyone to get the chance of having it.

\section{CONCLUSIONS AND RECOMMENDATIONS}

\section{Conclusions}

Potential customers for organic food are those aged 2849 years $(69 \%)$, working as employees and professionals $(49 \%)$. The most influential variable on purchasing decisions is marketing strategies, contributing 33.6\%. The better marketing strategy, especially related to distribution, the more likely customers will buy. In addition, to marketing strategies, a significant factor contributing to purchasing decisions is customer attitude, contributing $28.9 \%$. However, there are two variables that have no effect on purchasing decisions, namely social norms and impending barriers. This means that friends, co-workers, family and other social environments have no effect on purchasing decisions. Likewise with impending barries, in today's digital era, it is quite easy to make an online purchase for organic food.

\section{Recommendations}

The researchers would advise organic companies to have surveys in several areas because at the moment its only found in certain areas, but if they have their surveys, they can be able to identify to expand their area by providing it to all societies not just having enough of a certain society. This study was limited to Expat Community in greater Jakarta, as well this study was conducted by quantitative data and questionnaire. 
We would recommend future researchers to develop the research by using other alternative variables to look what kind of factors are influencing the purchase decision on organic food, also researcher may use different method like qualitative or even mix methods between quantitative and qualitative. Moreover, future researchers can widen the area of their research, do research on different group of people, or can be a different city, to find out what other factors affect the purchase decision on organic food.

\section{REFERENCES}

Aertsens J, Verbeke W, Mondelaeres K. 2009. Personal determinants of organic food consumption. British Food Journal 111(10): 1140-1167. https://doi.org/10.1108/00070700910992961

Aschemann-Witzel J. 2010. Do consumers prefer foods with nutrition and health claims? results of a purchase simulation. Journal of Marketing Communications 16(1/2): 47-58. https://doi. org/10.1080/13527260903342746

Bai G, Bai Y. 2020. Voluntary or forced: different effects of personal and social norms on urban residents' environmental protection behavior. International Journal of Environmental Research and Public Health 17(10): 3525-3542. https:// doi.org/10.3390/ijerph17103525

Bai L, Wang M, Gong S. 2019. Understanding the antecedents of organic food purchases: the important roles of beliefs, subjective norms, and identity expressiveness. Sustainability 11(11): 1-18. https://doi.org/10.3390/su11113045

Chiciudean G, Arion F, Muresan L. 2019. Organic food consumers and purchase intention: a case study in Romania. Agronomy 9(3): 145-158.https:// doi.org/10.3390/agronomy9030145

Choi JS. 2011. Food nutrition information, where can we get sources of nutrition information in food? Journal of Korean Diabetes 12(3):163-166. https://doi.org/10.4093/jkd.2011.12.3.163

Curvelo I, Wanatabe EA, Alfinito S. 2019. Purchase intenton of organic food under the influence of attributes consumer trust and perceived value. Emerald Insight 26(3): 198-211. https://doi. org/10.1108/REGE-01-2018-0010

Dhanavath S, Rao P. 2017. Nutritional and nutraceutical properties of triticum dicoccum wheat and its health benefits. Journal of Food Science 82(10): 2243-2250. https://doi.org/10.1111/1750-

\subsection{4}

Duh H. 2019. Marketing and socio-psychological factors influencing organic food purchase and post-purchase outcome. Journal of Food Products Marketing 25(10): 1-25. https://doi.or g/10.1080/10454446.2019.1697980

Genoveva G, Berliana W. 2021. Pengaruh green marketing mix terhadap brand image produk tupperware. Journal of Management and Business Review 18(1): 60-76. https://doi. org/10.34149/jmbr.v18i1.218

Ghosh S, Barai P, Datta B. 2018. Identify customer involvement during organic food purchase through FCB Grid. Journal of International Food and Agribusiness Marketing 31(3): 1-17. https://doi.org/10.1080/08974438.2018.152017 6

Gruchmann T, Wenzig J. 2018. Preferences for local food: testing an eextended norm taxonomy. Sustainability 1313-1336. https://doi. org/10.3390/su10051313

Hair J, Black BJ, Anderson RE. 2014. Multivariate Data Analysis (Vol. Seventh Editioon). New Jersey: Prentice Hall.

Ham M, Jeger M, Lvković AF. 2015. The role of subjective norms in forming the intention to purchase gfreen food. Economic ResearchEkonomska Istraživanja 28(1): 738-748. https:// doi.org/10.1080/1331677X.2015.1083875

Han TI, Stoel L. 2016. Understanding the effects of social norms and knowledge on socially responsible consumer behavior (SRCB). Journal of International Consumer Marketing 29(2): 1-13. https://doi.org/10.1080/08961530.2016.1 251870

Hawkins D, Mothersbaugh DL. 2015. Consumer Behavior: Building Marketing Strategy (Vol. Eleventh Edition). International Edition: McGraw-Hill Irwin.

Jansson J, Dorrepaal E. 2015. Personal norms for dealing with climate change: results from a survey using moral foundations theory. Sustainable Development 23(6): 391-395. https://doi.org/10.1002/sd.1598

Laureti T, Benedetti L. 2018. Exploring proenvironmental food purchasing behaviour: An empirical analysis of Italian consumers. Journal of Cleaner Production 172: 3367-3378. https:// doi.org/10.1016/j.jclepro.2017.11.086

Lee TH, Fu C, Chen Y. 2019. Trust factors for organic foods: consumer buying behavior. British 
Food Journal 122(2): 414-431. https://doi. org/10.1108/BFJ-03-2019-0195

Li X, Xin Y. 2015. Factors Influencing Organic Food Purchase of Young Chinese Consumers. Sweden: Uppsala Universitet.

Mishra P, Pandey CS, Gupta A, Sahu C, Keshr A. 2019. Descriptive statistics and normality tests for statistical data. Annals of Cardiac Anasesth 22(1): 67-72. https://doi.org/10.4103/aca. ACA_157_18

Nocella GK. 2012. Food health claims - what consumers understand. Food Policy 37(5): 571-580. https:// doi.org/10.1016/j.foodpol.2012.06.001

Nugroho T, Sumarwan U, Kirbrandoko. 2015. Factors influencing the purchase decision of organic tofu. Indonesia Journal of Business and Entrepreneurship 1(3): 115-126. https://doi. org/10.17358/IJBE.1.3.115

Onwezen M. 2015. I did good, and we did bad: the impact of collective versus private emotions on pro-environmental food consumption. Food Research International 76(2): 261-268. https:// doi.org/10.1016/j.foodres.2015.03.032

Peattie K. 2010. Green consumption: behavior and norms. Annual Review of Environment and Resources 35: 195-228.

Qasim H, Yan L, Saeed A. 2019. The defining role of environmental self-identity among consumption values and behavioral intention to consume organic food. International Journal of Environmental Research and Public Health 16(7): 1106-1128. https://doi.org/10.3390/ ijerph16071106

Ririn Y, Tantri S, Rina A. 2019. How packaging, product quality and promotion affect purchase intention. Russian Journal of Agricultural and Socio-Economic Sciences 92(8): 56-65. https:// doi.org/10.18551/rjoas.2019-08.06

Ruiz T, Zamora V, Rosa P. 2018. False barriers in the purchase of organic foods. the case of extra virgin olive oil in Spain. Sustainability 10(2): 461-475. https://doi.org/10.3390/su10020461

Selmer J. 2019. What is expatriate management? Journal of Global Mobility 7(3): 237-238. https://doi.org/10.1108/JGM-09-2019-073

Setiawati L, Chairy C, Syahrivar J. 2019. Factors affecting the intention to buy halal food by the millenial generation: the mediating role of attitude. Development Research of Management 14(2): 175-188. https://doi.org/10.19166/ derema.v14i2.1738
Sharma M, Triveldi P. 2016. Various green marketing variables and theirs effects on consumers' buying behavior for green products. IJLTEMAS V(I): $1-8$.

Suharjo B, Ahmady M, Ahmady MR. 2016. Indonesian consumers' attitudes towards organic products. Advances in Economics and Business 4(3): 132140. https://doi.org/10.13189/aeb.2016.040303

Sundqvist A. 2005. Subjective norms, attitudes and intentions of finnish consumers in buying organic food. British Food Journal 107(11): 808-822. https://doi.org/10.1108/00070700510629760

Teng C, Wang M. 2015. Decisional factors driving organic food consumption: generation of consumer purchase intentions. British Food Journal 117(3): 1066-1081.

Ueasangkomsatea P, Santiteerakulb S. 2016. A study of consumers' attitudes and intention to buy organic foods for sustainability. Procedia Environmental Sciences 34: 423-430. https://doi.org/10.1016/j. proenv.2016.04.037

Ursachi G, Zait A, Horodnic A. 2015. How reliable are measurement scales? External factors with indirect influence on reliability estimators. Procedia Economics and Finance 20: 679-686. https://doi.org/10.1016/S2212-5671(15)00123-9

Utami NN, Genoveva G. 2020. The influence of brand image, halal label, and halal awareness on customer purchasing decision of halal cosmetics. Jurnal Muara Ilmu Ekonomi Dan Bisnis 4(2): 355-365. https://doi.org/10.24912/ jmieb.v4i2.8381

Vega-Zamora M, Parras-Rosa M, Torres-Ruiz FJ. 2020. You are what you eat: the relationship between values and organic food consumption. Sustainability 12(9): 3900-3913. https://doi. org/10.3390/su12093900

Wang X, Pacho F, Liu J, Kajungiro R. 2019. Factors influencing organic food purchase intention in Tanzania and Kenya and the Moderating Role of Knowledge. Sustainability 11(1): 1-18. https:// doi.org/10.3390/su11010209

Widjajakusumah P. 2018. 2018 Annual report. Jakarta: Yayasan Usaha Mulia.

Wilcock A, Pun M, Khanona J, Aung M. 2004. Consumer attitudes, knowledge and behaviour: a review of food safety issues. Trends in Food Science and Technology 15(2): 56-66. https:// doi.org/10.1016/j.tifs.2003.08.004 